\title{
A Proposal Study on Indonesian Capital Market Integration With Cheung and Lee (1993) Asset Pricing Modification
}

\author{
Ignatius Roni Setyawan \\ Tarumanagara University, Jakarta, Indonesia
}

\begin{abstract}
Many studies claim that Indonesia capital market tends to be segmented. They both claim that due to weak correlation between stock returns in the Indonesian stock exchanges (formerly Jakarta stock exchange) with stock returns in other countries' stock exchanges, Indonesian capital market segmentation is justified. Their claims is further strengthened by such survey that not only claims that Indonesia market is segmented but also claims that Indonesian stock exchange is very attractive for foreign investors since this condition will bring the benefit of international diversification. Nevertheless, if further examined, the increase in foreign investor's activity in the IDX would cause the Indonesian Index (JCI) to be further influenced by the international factor carried by those foreign investors. This condition causes the segmentation of Indonesia capital market started to be questioned. Furthermore, some studies discover the co-integration phenomenon in the IDX post 1997 monetary crisis in East Asia. Next development is the occurrence of two major groups in capital market integration study. The first group is statistical perspectives who focuses on confirming the integration of capital market segmentation; while the other on seeking the determinants of capital market integration. For the second group, i.e., asset pricing perspectives has used ICAPM model to investigate the integration of segmentation of stock market. Some studies propose model which can be formulated such as $R_{i t}=\delta_{0}\left(1-\beta_{i}{ }^{m}\right)+\delta_{1} \beta_{i}{ }^{1}+\beta_{i}^{m} R_{m t}+\beta_{i}{ }^{1} F_{i t}+\varepsilon_{i t}$. While for this study, the author propose a modification model by extending some relevant variables as the determinant of integration or segmentation from the Indonesian capital market. Thus, the model was used in this study become into such empirical model as follows: $R_{i t}=\delta_{0}\left(1-\beta_{i}^{m}\right)+\delta_{1} \beta_{i}{ }^{1}+\delta_{2} \beta_{i}{ }^{2}+\delta_{3} \beta_{i}{ }^{3}+\delta_{4} \beta_{i}{ }^{4}+\delta_{4} \beta_{i}{ }^{5}+\beta_{i}{ }^{m} R_{m t}+\beta_{i}{ }^{1} F_{i t}+\beta_{i}{ }^{2} \mathrm{NBS}+\beta_{i}{ }^{3} \mathrm{CE}+\beta_{i}^{4} \mathrm{D}+\beta_{i}^{5} \mathrm{VOT}+\varepsilon_{i t}$.
\end{abstract}

Keywords: integration, segmentation, net foreign fund flow, cost of equity, asset pricing, Indonesian capital market

\section{Introduction}

Privatization of Indonesia capital market in 1992 made the Indonesian capital market open to foreign investors (Husnan \& Pudjiastuti, 1995). Roida (2004) argued that with the opening of Indonesian capital market, and then various external factors, either positive or negative will start to significantly influence it. Positive external factors among others are increasing foreign fund inflow-in the form of stocks purchase in Indonesia stock market (see the IDX) by foreign investors, this will encourage the rise of Index (JCI: Jakarta Composite Indices) (Roll, 1995; Wang, 2000; Frensidy, 2006). Meanwhile, the negative factors among others are the weakening (depreciation) of Rupiah exchange value against the US dollar that leads to negative perception the foreign investors have toward Indonesian capital market. Negative perception will cause negative sentiments 
among them which in turn will drive them to sell stocks they own, which eventually will cause the index to drop significantly. Therefore, the opening of Indonesia's capital market to foreign investor since 1992 (at 49\% level) and almost 100\% in the 2002 period indeed bring positive as well as negative changes to the Index (JCI) (Murtini \& Ekawati, 2003). At the time the foreign investor have positive sentiments, thus, positive impact happens as can be witnessed through the rise of JCI in the period 2004-2007 (Setyawan, 2007), at that time the JCI was in the range of 800-2,600. However, when negative sentiments occurred then the JCI will be sharply corrected. This historic experience of BEI (formerly BEJ) shows that during the July 1997 crisis, the IHGS was at its lowest level, at around 200 points. Moreover, during the 2007-2008 period, due to subprime mortgage crisis in the US and also oil prices crisis, the JCI was corrected from the 2600-2700 range to the 2100-2200 range. Since generally the main driving force of world's indices movements comes from the US, therefore, it is appropriate for Naranjo and Aris (1997) to declare that the New York stock exchange is the barometer for world's exchanges.

Thus, Indonesian capital market privatization toward the foreign investors contributes significant benefits toward Indonesia. Due to the deregulation for the foreign investors to invest in BEI (formerly BEJ), the Indonesian capital market experience positive impact. This is proven by the significant rise of JCI in periods of 1993-1996, and 2002-2007. Nevertheless, the presence of foreign investors also carries its own negative consequences as well, such as the sharp JCI depreciation in the 1997 monetary crisis, terrorists' bombing events (2002-2005), and during the international economy instability moments, namely, the sub-prime mortgage crisis and the sharp hike in oil prices during the period 2007-2008. Therefore, the developments of Indonesia's capital market since 1992-2008 cannot be taken separately from the presence of international investors and events. These situations cause the Indonesia's capital market under "floating" condition between integration which means opening up toward foreign investors and the international economic events or to shut itself from the foreign investors and the global economic events. Nevertheless, due to significant long term effect from economic globalization and the benefit of JCI rise, therefore the Indonesia market is advised to better off to open or integrate itself (Kleimeier \& Herald, 2000). However considering the negative effects that happen in the form of sharp JCI depreciation, it is advised that sometimes Indonesia should consider protecting itself from the negative sentiments of foreign investors and negative excess from the economic globalization.

In the author's point of view, Indonesia's capital market cannot abruptly opt between integration or segmentation, but the key is knows the moment of when to take the decision between the two options available. Thus far, Korajczyk (1995) argued that limitation for the foreign investors of local stock ownership can be an effective tool for Indonesia market to integrate or to be segmented. Nevertheless, in a related research by M. N. Gultekin, N. B. Gultekin, and Penati (1989), who argued that effective instrument did not just come not only in the form of limitation of stock ownership but also in the form of cost of equity that acts as a limitation for foreign investors.

On the other hand, as far as the academic world is concerned, many research topics on integration and segmentation show that no capital market in the world that have the extreme forms - whether fully integrated or perfectly segmented (Husnan \& Pudjiastuti, 1994). What commonly happens in the market is only the tendency to be segmented or to be integrated (Errunza \& Losq, 1985; Jorion \& Schwartz, 1986; Cheung \& Lee, 1993). A study by Faff and Mittoo (1998) indicates that the tendency is determined by the degree of one nation's development level. Generally, the markets in the developed nations tend to be integrated since they have strong economic basis to flow their funds to the developing nations, in addition to that, they also have proper 
preparation to bear the risks from the investments in the international markets (Kearney \& Lucey, 2004; Bracker, Diane, \& Paul, 1999).

As for the developing nations, they will tend to be segmented due to relatively weaker economic basis among others are unstable currency exchange value, low Gross National Product (GNP), and weak banking system. As a result, it would be wise to prioritize strengthening the basis for national economics before opening the capital markets to overseas investors. In Stulz and Wasserfallen's (1995) opinions, the pathway can be done by these nations are: (1) enacting direct barriers by imposing investment taxes for multinational companies; and (2) imposing indirect barriers by limiting access either for foreign multinational or for domestic investors to be related.

Now, one question might occur as to why the capital markets in the developing nations tend to be segmented. Cheung and Lee's (1993) study concludes that developing countries need to prepare their capital markets before allowing the foreign investors to come in. Preparation is needed to strengthen the competitiveness of domestic investors, since foreign investors generally have ample capital resources at their disposal. Due to this condition, overseas investors generally are eyeing strategic investments, namely, oil and gas, coal, gold, copper, and other mine-related investments. Hence, a segmented capital market would bring obstacles for investors abroad enter these strategic fields, and the opportunity to manage these will likely be prioritized to the domestic investors thereof. Concurrently, the potential benefit will likely be enjoyed by the relevant country and not going abroad. In addition to the above statements, this research aims to continue the study done by Cheung and Lee (1993) who found that Korean is a segmented capital market.

This study will apply the integration multifactor examination model and capital market segmentation that was developed by Jorion and Schwartz (1986) and used by Cheung and Lee (1993) (which will be discussed later) also by Cadwell (1997). This research is different than that of Cheung and Lee (1993) in regard to the utilization of international investment risk and research period ${ }^{1}$. There are two main problems identified on this research, the first one is why integration and capital market segmentation topic could occur? The second one is what can actually be learned upon the occurrence of this topic (upon the increasing attention on this particular topic) not only in economic benefit but especially in terms of modeling and research design. The writer assumes that this topic occurs due to globalization phenomena. Hardouvelis, Malliaropulos, and Priestley (2006) stated that the globalization phenomena which occurred in the early 1990s was due to the increasing interaction between foreign and domestic investor triggered by the privatization projects in the capital market particularly in the developing countries. The basis for his arguments was the more foreign investors participating in a new capital market, hence, the economic contribution. Since a rise in a stock prices index is related to the growth of GNP, therefore the result is the increasing research on this topic, since the academicians and practitioners also start to discuss on integration topic.

However with the Asia economic crisis in 1997, many countries started to think on the negative impact from globalization. In practice, many developing nations suspicion start to grow (Jang \& Sul, 2002). This is caused by the facts that many of them withdrew their funds and rushed part of their portfolio to the capital markets in the developed countries. This suspicion is manifested in the form of restriction, either in the tax hike

\footnotetext{
${ }^{1}$ Cheung and Lee (1993) study uses three kinds of international capital market investment risks, those are Asia Pacific, North America, and the world capital markets. Meanwhile, the writer only uses Asia Pacific capital markets under the fact that Indonesia capital market is located in the Asia region, therefore it is assumed that Asia Pacific's investment risk is the most dominant. Furthermore, Cheung and Lee (1993) study was conducted in the year 1982-1989, meanwhile the writer conducted his research from 1992-2008 in expectance that longer research period might contribute to the improvement of the quality of research analysis.
} 
or cost of equity, this would eventually make the investors to be reluctant to invest. Henceforth, the 1997 economic crisis, many discussions started to go to segmentation direction (Lam \& Pak, 1993; Choi \& Rajan, 1997, Domowitz, Glen, \& Madhavan, 1997; Foster \& Karolyi, 1999). During the early 2000s, among the developing nations, the realization of the importance of foreign investors began to flourish. It is related to the facts that their presence is able to invigorate the pertinent capital markets. During that period, many State owned enterprises in the developing world were privatized to foreign investors, these particular events brought economic benefits to the capital markets in those countries (Cha \& Sekyung, 2000). In the writer's point of view, the topic on integration segmentation is not conclusive, thus an empiric research on this subject is required. This is due to the fact that globalization indicates positive and negative impacts.

There are two research groups related, the first research group being statistic perspective and assert pricing (Yusof \& Madjid, 2006). This group generally uses correlation to co-integration methods. The writer sees this group tend to prove the time of when a capital market will be integrated and segmented ${ }^{2}$. Since many studies at the master's level have covered the study category, hence, the writer proposes to focus his study on the asset pricing $^{3}$. In general, this group uses ICAPM and IAPT approach that put assumptions of perfect market that the investors have freedom in engaging in international diversification, this means any measures of government's restrictions is decreasing (Koutoulas \& Kryzanowski, 1994). Through this asset pricing model, we can identify what factors that are related to the integration and segmentation of a capital market. According to Cheung and Lee (1993) and Basak (1996), minimum restriction and growing presence of foreign investors indicate that the capital market is integrated. Otherwise, if the markets increasingly reducing the ownership from foreign parties and enacting barriers such as cost of equity, hence, the capital market is segmented. As far as the writer's concerns, there is other foreign research on the dynamics on Indonesian market other than Roll (1995). Among others is Wang (2000) who shows that not only the presence of foreign investors do bring influence on the closing or opening of the capital market, in addition to that, he states that Indonesia's dynamic capital market (marked by the high volatility of stock returns) makes these investors to feel comfortable investing here. Since their presence will also become an example for the domestic investors in determining the related investment portfolio. Therefore, the writer's tentative presumption is the higher volatility of stock return is, the more integrated the capital market is, given the stable economic condition. Based on the above descriptions, then the main purpose of this research is to gain empirical evidences on:

- Whether Indonesia's capital market is segmented or integrated market-using asset pricing method;

- Two dominant factors (net buying (selling) and cost of equity) of foreign investors affecting the segmentation of integration of capital market;

- Influence of foreign investor's net buying (selling) and cost of equity to the segmentation of integration of

\footnotetext{
2 If there is a strong correlation of stock returns among stock markets, thus it is called integration. Otherwise, a low correlation indicate a segmentation (refer to Roll (1995) for Indonesia case). Meanwhile, according to Yusof and Madjid (2006), many researches have applied co-integration. If the value of unit root test either Augmented Dickey Fuller or Phillips Peron Tests are significant, signify integration. In future development, numerous researches have applied Error Correction Model (ECM) method based on Vector Autoregressive (VAR) methodology-Adopted from Engle-Granger Causality either bi-variate or multivariate. Even Bussetti and Manera (2003) also have also employed STAR-GARCH technique.

${ }^{3}$ Asset pricing has several advantages compared with statistic perspective base because not only it offers several ICAPM or IAPT application models that are increasingly coherent with dynamic factors (e.g., stock returns volatility and macro economic dynamism), but also offers explanation of how the integration or segmentation take place. According to writer integration or segmentation analysis with asset pricing base is most suitable for doctoral study category (Basak, 1996; Bekaert \& Harvey, 1995; Basak \& Croitoru, 2004; Bhamra, 2002).
} 
Indonesian capital market, and whether or not Indonesia's capital market is by and large influenced by 1997 monetary crisis;

- Influence form additional factor like the volatility of stock returns against the integrated or segmented condition of Indonesian market, beside the net buying (selling) and cost of equity from the foreign investor.

This study hopes to be able to provide empirical evidence on Indonesian capital market whether it is integrated or segmented. The reason behind this is the scarcity of research based on asset pricing that focuses on these two issues. To date, in Indonesia, research on this field is dominated with statistic perspective such as Roll (1995) and Roinda (2004). On their studies, they have different opinions on Indonesia's market, one argues that the market is segmented while the other states otherwise at different time. There is one study by Husnan and Pudjiastuti (1995), however, that offers relatively simple approach of asset pricing, a single factor CAPM that is. Alike with Murtini and Ekawati (2003), Frensidy (2006), and Setyawan (2007) that although focus on the relational model of net buying (selling) of foreign investors and the market index but basically still depend solely on logarithmic software EVIEWS (see VAR analysis menu and ARCH/GARCH). Therefore, the above study group is still categorized as statistic perspective research. In order to achieve the expectancies that is gaining a research model based on asset pricing, the writer intends to modify Cheung and Lee (1993) and Basak (1996) models considering that their models are much more dynamic - in a sense of being able to accommodate potential factors have not yet been covered in the previous researches - those are foreign investors net buying (selling), cost of equity, and stock return volatility.

For the investors and governments circle, this study wishes to be able to identify what kind of investment strategy and capital market regulations in Indonesia that can promote conducive financial atmosphere for foreign investors, yet at the same time they are able to minimize the worries of strong hold of these investors toward Indonesia's national economy. This eventually hopes to bring positive perspective for foreign investors toward Indonesia investment climate. Their presence is important because foreign investors many times are regarded as reference for the domestic investor to invest in the capital market.

\section{Literature Review}

\section{Integration and Capital Market Segmentation}

This part will explain the meaning of capital market integration and segmentation from three previous studies, those are: Cheung and Lee (1993); Stulz and Wasserfallen (1995); and Li and Primbs (2005). Cheung and Lee (1993) and Stulz and Wasserfallen (1995) discuss the comparison of operational definitions on integration and segmentation, whilst Li and Primbs (2005) emphasize on the forms of segmentations.

\section{Cheung and Lee (1993) Research}

Cheung and Lee (1993) represent the differences between integration and segmentation from the international investment risk perspective. For a perfectly integrated capital market, only domestic market risk should be considered. Meanwhile, the global market risk is deemed irrelevant and should not be accounted the way that the domestic investors do, since they cannot participate in the foreign market, and otherwise the foreign players in one domestic market.

Meanwhile, in a perfectly integrated market, not only the market risk should be accounted for but the global market risk alike. The argument is that the capital market is integral part of global capital market. So, every external influence of global capital market will influence the related capital market. 


\section{Stulz and Wasserfallen (1995) Research}

Stulz and Wasserfallen (1995) present the integration and segmentation from domestic investor's domination against the foreign investor's perspective. In a segmented market, domestic investors have more opportunities to enjoy expected return more than foreign investors since he or they have bigger chances investing in strategic projects due to larger share in those projects. In a segmented type, it can be said that domestic investors do not bear the risks related to international investments, they only bear those which related to domestic ones. In the integrated capital market, a domestic investor would compete against the foreign players in attempts to win strategic projects since both competing on the level playing field. In order to enjoy a fair expected returns, thus domestic investors need to diversify internationally to minimize their risks.

\section{Li and Primbs (2005) Research}

$\mathrm{Li}$ and Primbs (2005) were able to develop a segmented capital market model under assumption of the absence of arbitrage process. Due to arbitrage process, foreign players had to diversify internationally to mitigate the currency exchange risks. According to them, arbitrage process in international markets has to be limited. They made an astounding definition in regard to segmentation, quoted as:

"Capital market is segmented if investments from a circle of investors are limited to a group of asset classes”.

Investments restrictions can be applied significantly, in the exhibit below portraying A and B in the China capital market, or restrictions come from within the investors to only acquire domestic stocks (behavioral finance is called as home bias).

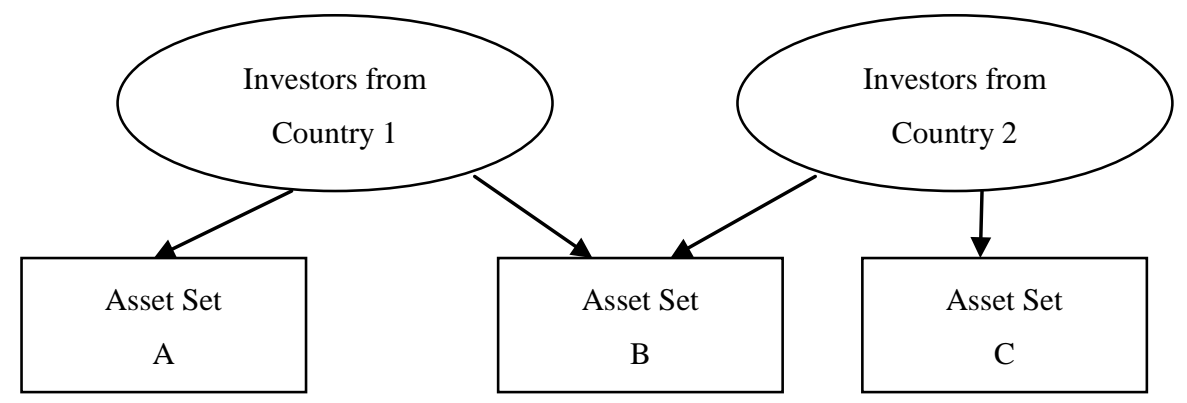

Figure 1. Li’s capital market segmentation model (2005).

Main contribution from $\mathrm{Li}$ and Primbs (2005) is not only able to depict segmentation concept in diagram as it can be seen from Figure 1, but also able to make asset pricing model in a segmented capital market. The base for his arguments is orthogonalization process that involves elements such as stochastic discount factor, beta, and factor model to maximize Constant Absolute Risk Aversion (CARA) on the Gaussian single period setting.

\section{Previous Empirical Studies}

Sthele (1977) was the first researcher who empirically tested the segmentation versus integration issues. Using Fama-McBeth (1973) technique, Sthele could not resist the hypothesis of segmentation or integration for USA capital market versus the world. Using a more powerful approach that is maximum likelihood, Jorion and Schwartz (1986) found that Canadian market was considered as an integrated market with the North America.

This issue on the Korean market was empirically tested by Errunza, Losq, and Padmanabahan (1992). With a total sample of just 12 companies, they found that the Korean market was the best candidate for a 
segmented capital market. Cheung and Lee (1993) did this examination on the Korean capital market and gained results that was a segmented market against three other markets, those are Asia Pacific, North America, and the world.

Through multivariate vector autoregressive method, Yusof and Madjid (2006) showed that the Japan's capital market on the Malaysia's market is dominant relative to the US', these events took place before and after the monetary crisis. The important meaning of capital market integration is the non-existence of gain from currency disparities in the international diversification process. The lesson that can be learned in an integrated market is that there will be arbitrage process that will have cancel out effect on all potential of abnormal returns from international diversification.

Integration versus segmentation research topic has been done by several researchers using CAPM market model and also CAPM non-market model. Those who ascribe to CAPM non-market model among others are Roida (2004), Frensidy (2006), and Setyawan (2007). Although these three used different methodologies, nevertheless, they were able to have similar outcomes that Indonesian market tends to be integrated.

Meanwhile for the CAPM market model group such as Husnan and Pudjiatusti (1995), and Roll (1995) backed by pre-1997 crisis data, found that Indonesia market model is segmented. Based on the results from these two groups there would raise a question, whether or not there is any contradiction between the CAPM non-market model and the market model. The writer argues that there is not any, in his opinion, it is logical that in the pre-1997 crisis, the market is segmented due to restrictions on stock ownership against the foreign investors. Meanwhile, post crisis, once the restrictions were lifted, thus the Indonesian market tends to be integrated.

\section{Hypothesis Development}

\section{Integration Versus Segmentation in the Indonesian Capital Market}

Since its founding in 1977, Indonesian capital market was a small market. At that time not many companies were listed owing to the fact that at the time the go public was not a trend among the business circle. However, started from the 1980s till the 1990s, Indonesia’s capital market started to experience sharp growth in line with a robust economic growth. Business community started to realize the benefits investing in the capital market, therefore, many companies were listing in the then BEJ. Moreover, following the go public trend in early 1990s, were the sharp increase in capitalization in some of the listed companies there. In 1992, the market was opened for the foreigners, following the capital market privatization by the government. Foreign investors started to be allowed to participate in an ownership in a corporation until the maximum $49 \%$. Foreign presence brought about rapid growth in the market (Murtini \& Ekawati, 2003).

From the descriptions above, we can bring into perspective that the Indonesian market condition before the 1992 and after 1992. Before 1992, the market was considered as a segmented one. This hypothesis was supported by Roll (1995) who claimed that the correlation between Indonesian capital market with its counterparts in the Asia Pacific region tend to be negative and weak (due to $p$-value above 5\%). Meanwhile after 1992, although its capital market started to be opened to foreign fund, it was not necessarily mean the market abruptly integrated. It was owing to the fact of the taxation tariff imposed on the multinational companies and restrictions on the amount of ownership allowed to the foreign investors. The condition in Indonesia was similar with Korea, despite its market has been opened for foreign players, Cheung and Lee (1993) supported this fact, declaring that Korea's market was considered as a segmented capital market. Based 
on the above description, a hypothesis can be made as follows:

H1: Generally, Indonesian capital market was categorized a segmented market.

\section{Several Determining Factors in Indonesian Capital Market}

There are at least two determining factors affecting the pattern or form of a capital market, those are foreign investor's net buying (selling) and cost of equity. Investor's net buying (selling) indicate foreigner's participation to the development of one nation's capital market. The higher of the participation is, the higher the influence of international investments effects will be on the related market. According to Errunza (1999), an increasing participation of foreign players will increase the information access related to international investment in the pertaining capital market.

Cost of equity shows cost of capital from an investment project. The higher the cost of equity is, the higher the cost of capital market of an investment project will be. In international diversification context, then a high cost of equity will make foreign investors reluctant to invest (Stulz, 1995). A high cost of equity is caused by a poor conditions of one nation (be it an unstable economy or politic) that eventually drive the country risk higher. It could be the government's policy to limit foreign ownership by imposing higher investment tax tariff (Stulz \& Wasserfallen, 1995). When one market is integrated then the capital market will be opened to foreign investors, as a result the net buying (selling) will increase, and thus the market capitalization will increase. Increase in market capitalization will facilitate the efforts to seek funding, eventually it will cause decrease in cost of equity.

Otherwise would prevail for segmented capital market. A segmented capital market tends to be closed against foreign investors, as a result is decrease in net buying (selling) and eventually the market caps will decrease. This condition will complicate efforts to seek funding.

Based on the above descriptions, therefore hypotheses can be drawn as follows:

H2a: Foreign investors' net buying (selling) bring negative impacts to Indonesia's capital market segmentation.

H2b: Cost of Equity brings positive impacts to Indonesia's capital market segmentation.

\section{Integration vs. Segmentation in Capital Market During 1997}

Through correlation analysis during the pre-monetary crisis, Roll (1995) says that Indonesia has segmented characteristic in its market. He says numerous negative marks found in his study do not indicate segmentation or integration, but the degree of correlation significance that if it shows above $5 \%$ indicates support for a segmented condition. Meanwhile Roida (2004) also employing correlation analysis was successful in presenting that after crisis Indonesia has stronger relations with Korea, Malaysia, Philippines, Hong Kong, Japan, and Taiwan than before. Strong evidence indicating these relationships can be traced to $p$-value of each correlation that reaches below 5\%. Thus Roida (2004) claimed that after Indonesian monetary crisis, its capital market tends to be integrated. When related to Frensidy (2006) and Setyawan's (2007) studies, foreign investors' fund inflow rose drastically after the monetary crisis in 1997. Based upon above descriptions, hypothesis as below can be drawn:

H3: 1997 monetary crisis shifted the integration form segmentation into integration.

\section{Contribution in the Stock Return Volatility to Integration or Segmentation}

There are two important studies on the stock return volatility and trading frequencies in Indonesian market, those are Neal et al. (1999) and Wang (2000). The writer tends to apply Wang's (2000) study since Wang was 
able to present an interesting event that with the higher volatility in this market would make investor more attracted. This condition would eventually drive domestic investors to follow suit, thus a herding effect as Neal et al. (1999) claim. Therefore can be seen the importance of foreign investors in regard to capital market's growth. According to Bhamra (2002), the increasing existence of foreign players will make the distance between upper and lower range of stock price index to be wider for they purchase stock in huge volume. Upon these statements, can be drawn a hypothesis as follows:

H4: Stock return volatility causes the shift in Indonesia stock market from segmented to integrated form.

\section{Research Method}

\section{Analysis Unit and Brief Research}

Definition of analysis unit from this research is the most active stock in the Jakarta Stock Exchange (changed to Indonesian Stock Exchange ever since 2007). Using purposive sampling method, the writer estimates there are at least five most active and most active stocks along 1992-2008. Most active criteria are based on market capitalizations during the 1992-2008 period, while most exist based on the beginning point when these companies were first listed in the bourse. Alike with Cheung and Lee (1993), this research applies portfolio combination to fulfill observations amount requirements needed in analysis model (p. 11). The five stocks selected are TLKM, INDF, ASII, UNVR, and HMSP.

Research procedure in brief covers: (1) Period of testing is divided into two: pre-crisis (1992-1997) and post crisis (1998-2008); and (2) Formation pattern of portfolio consist of two stock and stock sorting are based on $\beta_{i}$ and Size. If in the end there are four stocks that translates into 10 portfolio combinations, those are TLKM-INDF, TLKM-ASII, TLKM-UNVR, and UNVR-HMSP.

\section{Operational Definitions and Data Source}

This study analyzes several research variables such as:

(1) Corporate stock return (Symbol: $R_{i t}$ ) $\rightarrow$ Weekly Data

Is defined as stock price difference in a $t$-period and $t-1$ period divided with a stock price in $t$ - 1 period. Stock price accessed from Jakarta Stock Exchange Monthly from January 1992 until December 2008 and from online download in the trading information section.

(2) Indonesia capital market return (Symbol: $R_{m t}$ ) $\rightarrow$ Weekly Data

Defined as a composite of returns from market index of listed companies in the Indonesian Stock Exchange. Market index source comes from the Far Eastern Economic Review (FEER) during 1992-2008 that published the JCI (Indonesian Composite Index) in the US\$. Indonesian index can also be seen in the indices part.

(3) World capital market returns (Symbol: $R_{w t}$ ) $\rightarrow$ Weekly Data

Defined as difference between Pacific index in the $t$ period and $t-1$ period divided against the Pacific index in the $t-1$ period. The data is gained from OSIRIS, PPIM-UI, and PACAP (PPA/MM-UGM) databases. Index value is not defined in currency unit, therefore it is not affected by the currency exchange value. The data is then used to figure $F_{i t}$ value which is the excess value from $R_{w t}=\lambda_{0}+\lambda_{1} R_{m t}$ equation. $F_{i t}$ is core component in integration versus segmentation model. Hence, $F_{i t}$ should be accurately identified through equation (2).

(4) Foreign investors net buying (selling) (Symbol: NBS) $\rightarrow$ Weekly Data

Is defined as difference between stock purchase or sales by foreign investors. This variable has similarities 
with foreign ownership portion used in Wang's (2000) study. However, in writer's point of view, foreign ownership proxy recorded in BEJ publication is not suffice in details, consequently the writer opted with NBS variable instead. NBS (Retrieved from http://www.bapepam.go.id) in the market summary section.

(5) Cost of equity (Symbol: CE) $\rightarrow$ Weekly Data

Implicitly, Cheung and Lee (1993) states the definition for CE as return on equity (ROE). If ROE is decided to be used then the writer has to seek weekly ROE, which is not available in the address http://www.idx.co.id. Due to data unavailability, for that reason the writer uses SBI as proxy with the data source comes from http://www.bi.go.id.

(6) Stock return volatility (Symbol: VOT) $\rightarrow$ Weekly Data

Is defined as stock return volatility. In order to be more effective, the writer will use Parkinson and Garman-Klass volatility type as quoted by Wang (2000). Stock return is counted using stock prices changes, with the source comes from Jakarta Stock Exchange Monthly from January 1992-December 2008 or from downloadable online source from http://www.idx.co.id in the trading information section.

\section{Hypothesis Testing Model}

This research will apply multifactor model in integration vs. segmentation market testing based on development on two-factor model from Cheung and Lee (1993) study. ${ }^{4}$ Multifactor model for H1 and H2a and $\mathrm{H} 2 \mathrm{~b}$ can be presented as below (Complete verification on multifactor model can be seen in detailed in equation (1)-(9)):

Generally can be seen as follows:

$$
R_{i t}=\delta_{0}\left(1-\beta_{i}^{m}\right)+\delta_{1} \beta_{i}^{1}+\delta_{2} \beta_{i}^{2}+\delta_{3} \beta_{i}^{3}+\beta_{i}^{m} R_{m t}+\beta_{i}^{1} F_{i t}+\beta_{i}^{2} \mathrm{NBS}+\beta_{i}^{3} \mathrm{CE}+\varepsilon_{i t}
$$

where:

$\mathrm{R}_{\mathrm{it}}$ : individual stock return analyzed on portofolio level;

$R_{m t}$ : Indonesia capital market return;

$F_{i t}$ : international extraction factor between $R_{m t}$ and $R_{w t}$;

$\beta_{i}{ }^{1} ; \beta_{i}{ }^{2} ; \beta_{i}^{3} ; \beta_{i}^{m}$ : loading factors that would be gone upon model running;

$\delta_{1} ; \delta_{2} ; \delta_{3}$ : each international coefficient factor, NBS and CE;

$\delta_{0}$ : constants.

H1 will be accepted if $\delta_{1}=0$ (significant at 5\% level). Meanwhile H2a and H2b will be accepted if $\delta_{2}<0$ and $\delta_{3}>0$ who is respectively significant at $5 \%$ level. International factor extraction procedure using Cheung and Lee model (1993) is as follows:

$$
F_{i t}=R_{w t}-\left(\delta_{0}+\delta_{1} R_{m t}\right)
$$

where:

$\delta_{0} ; \delta_{1}$ are regression coefficient;

$R_{w t}$ is return of world market indices such as MSCI and DJIA.

Model 2 is an important part to model 1 . As for model 1 there are stages for its estimates. Research modification of Jorion and Schwartz (1986):

$$
R_{i t}=E\left(R_{i t}\right)+\beta_{i}^{m}\left[R_{m t}-E\left(R_{m t}\right)\right]+\beta_{i}^{1} F_{i t}+\varepsilon_{i t}
$$

\footnotetext{
${ }^{4}$ In order to be able to work optimally, the multifactor model will be done with analysis factor technique that will integrate all factors on that model in order to reach a convergent result. The reason to select this analysis factor is because this technique is considered GLS family.

${ }^{5}$ It is extension of Black (1972) CAPM as quoted by Cheung and Lee (1993).
} 


$$
\begin{gathered}
\mathrm{E}\left(R_{i t}\right)=\delta_{0}+\delta_{m} \beta_{i}^{m}+\delta_{1} \beta_{i}^{1} \\
R_{i t}=\delta_{0}+\delta_{1} R_{m t}-F_{i t} \\
\mathrm{E}\left(R_{m t}\right)=\delta_{0}+\delta_{m} \\
F_{i t}=R_{i t}-\delta_{0}-\delta_{1} R_{m t}
\end{gathered}
$$

For Cheung and Lee (1993) research modification is the substitution equation (4a) s/d (5b) to equation (3):

$$
\begin{gathered}
R_{i t}=\delta_{0}+\delta_{m} \beta_{i}^{m}+\delta_{1} \beta_{i}{ }^{1}+\beta_{i}^{m}\left(R_{m t}-\delta_{0}-\delta_{m}\right)+\beta_{i}{ }^{1} F_{i t}+\varepsilon_{i t} \\
R_{i t}=\delta_{0}+\delta_{m} \beta_{i}^{m}+\delta_{1} \beta_{i}{ }^{1}+\beta_{i}^{m} R_{m t}-\delta_{0} \beta_{i}^{m}-\delta_{m} \beta_{i}^{m}+\beta_{i}{ }^{1} F_{i t}+\varepsilon_{i t} \\
R_{i t}=\delta_{0}-\delta_{0} \beta_{i}{ }^{m}+\delta_{1} \beta_{i}{ }^{1}+\beta_{i}^{m} R_{m t}+\beta_{i}{ }^{1} F_{i t}+\varepsilon_{i t} \\
R_{i t}=\delta_{0}\left(1-\beta_{i}{ }^{m}\right)+\delta_{1} \beta_{i}{ }^{1}+\beta_{i}{ }^{m} R^{m t}+\beta_{i}{ }^{1} F_{i t}+\varepsilon_{i t}
\end{gathered}
$$

Writer's modification by expanding NBS and CE in equation (6), equation expansion (2), substitution equation (7) into equation (6) as follows:

$$
\begin{array}{r}
R_{i t}=\mathrm{E}\left(R_{i t}\right)+\beta_{i}^{m}\left[R_{m t}-\mathrm{E}\left(R_{m t}\right)\right]+\beta_{i}{ }^{1} F_{i t}+\beta_{i}{ }^{2} \mathrm{NBS}+\beta_{i}{ }^{3} \mathrm{CE}+\varepsilon_{i t} \\
\mathrm{E}\left(R_{i t}\right)=\delta_{0}+\delta_{m} \beta_{i}^{m}+\delta_{1} \beta_{i}{ }^{1}+\delta_{2} \beta_{i}{ }^{2}+\delta_{3} \beta_{i}^{3} \\
R_{i t}=\delta_{0}+\delta_{m} \beta_{i}^{m}+\delta_{1} \beta_{i}{ }^{1}+\delta_{2} \beta_{i}{ }^{2}+\delta_{3} \beta_{i}^{3}+\beta_{i}^{m} R_{m t}-\delta_{m} \beta_{i}^{m}+\beta_{i}{ }^{1} F_{i t}+\beta_{i}{ }^{2} \mathrm{NBS}+\beta_{i}{ }^{3} \mathrm{CE}+\varepsilon_{i t} \\
R_{i t}=\delta_{0}\left(1-\beta_{i}^{m}\right)+\delta_{1} \beta_{i}{ }^{1}+\delta_{2} \beta_{i}{ }^{2}+\delta_{3} \beta_{i}{ }^{3}+\beta_{i}{ }^{m} R_{m t}+\beta_{i}{ }^{1} F_{i t}+\beta_{i}{ }^{2} \mathrm{NBS}+\beta_{i}^{3} \mathrm{CE}+\varepsilon_{i t}
\end{array}
$$

First hypothesis (H1) that Indonesia capital market is a segmented market will be accepted if $\delta_{1}=0$ meaning the influence from international capital market return to Indonesia's market is significantly not exist. For H2a can be accepted if the coefficient of $\delta_{2}<0$ and significant at 5\% level. It has implication that NBS (Net Buying Selling) variable significantly bring positive value which means that statistically that Indonesian capital market (IDX) is segmented. While H2b shall be accepted if coefficient of $\delta_{3}>0$ which implicate that the Cost of Equity (CE) variable significantly bring positive value which it means IDX have still indicated as the segmented capital market.

For purpose of testing $\mathrm{H} 3$ and $\mathrm{H} 4$ shall be done model transformation from equation (9) into each of these:

$$
\begin{gathered}
R_{i t}=\delta_{0}\left(1-\beta_{i}^{m}\right)+\delta_{1} \beta_{i}^{1}+\delta_{2} \beta_{i}{ }^{2}+\delta_{3} \beta_{i}^{3}+\delta_{4} \beta_{i}^{4}+\beta_{i}^{m} R_{m t}+\beta_{i}^{1} F_{i t}+\beta_{i}^{2} \mathrm{NBS}+\beta_{i}^{3} \mathrm{CE}+\beta_{i}^{4} \mathrm{D}+\varepsilon_{i t} \\
R_{i t}=\delta_{0}\left(1-\beta_{i}^{m}\right)+\delta_{1} \beta_{i}^{1}+\delta_{2} \beta_{i}^{2}+\delta_{3} \beta_{i}^{3}+\delta_{4} \beta_{i}{ }^{4}+\beta_{i}^{m} R_{m t}+\beta_{i}^{1} F_{i t}+\beta_{i}^{2} \mathrm{NBS}+\beta_{i}^{3} \mathrm{CE}+\beta_{i}^{4} \mathrm{VOT}+\varepsilon_{i t}
\end{gathered}
$$

Otherwise the equation (10) and (11) could be merged into one equation such as:

$$
\begin{gathered}
R_{i t}=\delta_{0}\left(1-\beta_{i}{ }^{m}\right)+\delta_{1} \beta_{i}{ }^{1}+\delta_{2} \beta_{i}{ }^{2}+\delta_{3} \beta_{i}{ }^{3}+\delta_{4} \beta_{i}{ }^{4}+\delta_{5} \beta_{i}^{5}+\beta_{i}{ }^{m} R_{m t}+\beta_{i}{ }^{1} F_{i t}+\beta_{i}{ }^{2} \mathrm{NBS} \\
+\beta_{i}{ }^{3} \mathrm{CE}+\beta_{i}{ }^{4} \mathrm{D}+\beta_{i}{ }^{5} \mathrm{VOT}+\varepsilon_{i t}
\end{gathered}
$$

$\mathrm{H} 3$ and $\mathrm{H} 4$ shall be accepted if the $\delta_{4}$ and $\delta_{5}$ of that model above (equation 12) has value larger than zero and significant at $5 \%$ level respectively. It could be meant that the 1997 monetary crisis and volatility of stock return respectively would have been shifting the condition of segmentation from Indonesian stock exchange (IDX) into term of the integration capital market.

\section{References}

Basak, S. (1996). An intertemporal model of international capital market segmentation. Journal of Financial and Quantitative Analysis, 31(2), 161-188.

Basak, S., \& Croitoru, B. (2005). International good market segmentation and financial innovation. Journal of International Economics, 71, 267-293.

Bekaert, G., \& Harvey, C. R. (1995). Time-varying world market integration. Journal of Finance, 50, 403-444.

Bhamra, S. H. (2002). International stock market integration: A dynamic general equilibrium approach (pp. 1-79). Retrieved from http://www.ssrn.com

Bracker, K., Diane, S., \& Paul, D. K. (1999). Economic determinant of evaluation in international stock market integration. Journal of Empirical Finance, 6, 1-27. 
Busetti, B., \& Manera, M. (2003). STAR-GARCH models for stock market interactions in the pasific basin region, Japan and US (pp. 1-34). Retrieved from http://www.ssrn.com

Cadwell, S. P. (1997). Integration versus segmentation of the Canadian and US stock markets: A multifactor asset pricing model approach (pp. 1-59). UMI Thesis Services, University of Michigan Ann Arbor.

Cha, B., \& Sekyung O. (2000). The relationship between developed equity market and the pasific basin’s emerging equity markets. International Review of Economics and Finance, 9, 299-322.

Cheung, C. S., \& Lee, J. (1993). Integration versus segmentation in the Korean stock market. Journal of Business, Finance and Accounting, 20(2), 267-273.

Choi, J. J., \& Rajan, M. (1997). A joint test of market segmentation and exchange risk factor in international capital markets. Journal of International Business Studies, 28(1), 29-49.

Domowitz, I., Glen, J., \& Madhavan, A. (1997). Market segmentation and stock prices: Evidence from an emerging market. Journal of Finance, 52(3), 1059-1085.

Errunza, V., \& Losq, E. (1985). International asset pricing under mild segmentation: Theory and test. Journal of Finance, 40, 105-124.

Errunza, V., \& Miller, D. (2000). Market segmentation and the cost of capital in international equity market. Journal of Financial and Quantitative Analysis, 35, 577-600.

Errunza, V., Losq, E., \& Padmanabahan, P. (1992). Test of integration, mild segmentation and segmentation hypothesis. Journal of Banking and Finance, 16, 949-972.

Erunza, V. (1999). Foreign portfolio equity investment in economic development (pp. 1-40). Retrieved from http://www.ssrn.com

Faff, R. W., \& Mittoo, U. R. (1998). Capital market integration and industrial structure: The case of Australia, Canada and the United States (pp. 1-60). Retrieved from http://www.ssrn.com

Foster, S. R., \& Karolyi, G. A. (1999). The effects of market segmentation and investor recognition on asset prices: Evidence from foreign stocks listing in the U.S.. Journal of Finance, 54, 981-1013.

Frensidy, B. (2006). The effect of net foreign fund flow and change of foreign exchange toward JCI movement in IDX (pp. 1-11). Research Proposal for Seminar on Behavioral Finance, Doctoral Program of Indonesian University (UI).

Gultekin, M. N., Gultekin, N. B., \& Penati, A. (1989). Capital controls and international capital market segmentation: The evidence from Japanese and American stock market. Journal of Finance, 44(4), 849-869.

Hardouvelis, G. A., Malliaropulos, D., \& Priestley, R. (2006). EMU and European stock market integration. Journal of Business, 79(1), 365-392.

Husnan, S., \& Pudjiastuti, E. (1995). International diversification: Observation on several capital markets in Asia Pasific (pp. 1-12). Working Paper from UGM.

Jang, H., \& Sul, W. (2002). The Asian financial crisis and the comovement of Asian stock market. Journal of Asian Economics, 13, 94-104.

Jorion, P., \& Schwartz, E. (1986). Integration versus segmentation in the Canadian stock market. Journal of Finance, 41(3), 603-612.

Kearney, C., \& Lucey, B. M. (2004). International equity market integration: Theory, evidence and implications. International Review of Financial Analysis, 13, 571-583.

Kleimeier, S., \& Herald, S. (2000). Rationalization versus globalization in European financial market integration: Evidence from cointegration analysis. Journal of Banking and Finance, 24, 1005-1043.

Korajczyk, R. (1995). A measure of stock market integration for developed and emerging markets (pp. 1-48). The World Bank Working Paper No. 1482.

Koutoulas, G., \& Kryzanowski, L. (1994). Integration or segmentation of the Canadian stock market: Evidence based on the APT. Canadian Journal of Economics, 27(2), 329-351.

Lam, S. S., \& Pak, H. S. (1993). A note on capital market segmentation: New tests and evidence. Pasific Basin Finance Journal, 1, 263-276.

Li, Q., \& Primbs, J. A. (2005). Asset pricing in hierarchical segmented market (pp. 1-41). Retrieved from http://www.ssrn.com

Mitchener, K. J., \& Ohnuki, M. (2007). Capital market integration in Japan. Monetary and Economic Studies, 25(11), 129-153.

Murtini, U., \& Ekawati, E. (2003). Integration of IDX with another bourses in ASEAN (After of eliminating the restriction of number of buying stock for foreign investors). Journal of Indonesian Accounting Research, 6(3), 304-319.

Naranjo, A., \& Aris, P. (1997). Financial market integration tests: An investigation using US equity markets. Journal of International Financial Markets, Insitutions and Money, 7, 93-135. 
Nath, G. C., \& Samanta, G. P. (2005). Integration between forex and capital markets in India: An empirical exploration (pp. 1-11). Retrieved from http://www.ssrn.com

Neal, B. C., Jones, S. L., Linnan, D., \& Neal, R. (1999). Herding and feedback trading by foreign investors: The case of Indonesia during Asian financial crisis (pp.1-20). Working Paper from European Financial Management Association.

Roida, H. Y. (2004). Integration versus segmentation in the Asian financial market: The prospect of regionalism in Asia (pp. 1-10). Working Paper of UWM.

Roll, R. (1995). An empirical survey of Indonesian equity 1985-1992. Pasific Basin Finance Journal, 3, 159-192.

Setyawan, I. R. (2007). The effect of net buying (Selling) of foreign investors and change of foreign exchange toward movement of JCI: Observation sample from 15 May 2006 until 22 December 2006. Journal of Business, Economy and Accounting Ventura, 10(3), 75-86.

Sthele, R. (1977). An empirical test of the alternative hypotheses of national and international pricing of risky assets. Journal of Finance, 32(5), 493-502.

Stulz, R. M. (1995). The cost of capital in internationally integrated markets: The case of Nestle. European Financial Management, 1(3), 11-22.

Stulz, R. M., \& Wasserfallen, W. (1995). Foreign equity investment restrictions, capital flight and shareholder wealth maximization: Theory and evidence. Review of Financial Studies, 8(Winter), 1019-1057.

Surjawan, A. G. (2007). Overview of co-integration between investment value of foreign and domestic investors with LQ45, O/N JIBOR and IDR/USD foreign exchange rate (pp. 1-77). Summary of Dissertation, Doctoral Program of Indonesian University (UI).

Wang, J. (2000). Foreign trading and market volatility in Indonesia (pp. 1-25). Working Paper from UNSW.

Yusof, R. M., \& Madjid, M. S. A. (2006). Who moves the Malaysian stock market: The U.S. or Japan? Empirical evidence from the pre, during and post-1997 Asian financial crisis. Gadjah Mada International Journal of Business, 8(3), 367-406. 